\title{
NIZOZEMSKA ISTOČNOINDIJSKA KOMPANIJA
}

\author{
Omer Merzić \\ Filozofski fakultet Univerziteta u Sarajevu \\ Odsjek za historiju \\ omer.merzic@gmail.com \\ Stručni rad \\ Primljeno: 20. 2. 2019. \\ Prihvaćeno: 16. 10. 2019.
}

\begin{abstract}
Nizozemska istočnoindijska kompanija jedna je od najznačajnijih kompanija u povijesti čovječanstva. U njenom višestoljetnom postojanju ona je promijenila dotadašnju ekonomsku praksu, koja i danas postoji. U ovom radu je dat kraći pregled povijesti Nizozemske istočnoindijske kompanije počevši od nastanka Nizozemske i njenog jačanja do te mjere da ta novonastala država može parirati Engleskoj. Predstavljena je kronologija Nizozemske istočnoindijske kompanije od njenog nastanka do njenog gašenja, te su data njena postignuća tijekom postojanja kompanije.
\end{abstract}

Ključne riječi: moderno doba, trgovina, Nizozemska, Istočne Indije

\section{Uvod}

Nizozemska istočnoindijska kompanija ${ }^{1}$ za svojeg višestoljetnog postojanja uspjela je napraviti revoluciju u ekonomskom sustavu tadašnje Europe i učiniti iskorak u poslovanju, koji je za rezultat imao veliki utjecaj i korist za tadašnji svjet, kao i za današnji. Njen model poslovanja uveo je u Europu prve naznake modernog pristupa i nagovjestio neizbježne promjene koje su se trebale dogoditi. Osim ekonomskog, kompanija je imala i kulturološki i politički utjecaj na tadašnji svjet. Njena mogućnost uspostavljanja jake trgovinske i pomorske mreže unutar azijskog tržišta, kao i način povezivanja europskog i azijskog tržišta je rezultirala ekonomski procvat Europe i sve veći zamah iste prema Aziji.

$\mathrm{Na}$ ovu temu je napisano na stotine knjiga i svake godine izlaze nove. Te knjige nisu isključivo povijesne i stručne, već postoje i one koje spadaju u popularno štivo i koje za glavnu temu imaju upravo

1 Naziv na nizozemskom jeziku je Vereenigde Oostindische Compagnie ili skraćeno VOC. Prijevod izvornog imena je Ujedinjena istočnoindijska kompanija, ali se u historiografiji tako rijetko naziva zbog postojanja više istočnoindijskih kompanija iz različitih država. Sve kompanije su dobile naziv po svojim državama. Zbog toga je i u našoj historiografiji zastupljen naziv Nizozemska istočnoindijska kompanija. 
kompaniju. To je jedan pokazatelj koji upućuje na važnost ove teme. Za izradu ovog rada najviše su korištena djela i članci autora kao što su "Principals and Agents, Colonialists and Company Men: The Decay of Colonial Control in the Dutch East Indies”, „Dutch Ships in Tropical Waters: The Development of the Dutch East India Company", „Capitalism and accounting in the Dutch East-India Company 1602-1623: a historical study of determining influences and practices" te mnoga druga djela.

Rad je u prvom dijelu pisan kronološkom metodom i tu je predstavljeno stanje u Europi koje je dovelo do nastanka Nizozemske, koja je bila jedna od najliberalnijih država tog vremena. Nakon nastanka Nizozemske pripreman je teren za formiranje kompanije i njen rad. Upravo o tome govori nastavak rada i to u kontekstu formiranja $\mathrm{Ni}$ zozemske istočnoindijske kompanije, njen rast do zenita njene moći i na kraju njeno postepeno slabljenje i gašenje. U drugom dijelu, upotrebljena je tematska metoda i tu ima govora o ostavštini kompanije u današnjem vremenu. U radu se nalazi podnaslov u kojem su uvrštene tablice koje prikazuju razvitak kompanije.

Cilj rada je pokazati značaj Nizozemske istočnoindijske kompanije i njen povijesni razvoj. Također je interesantno bilo istraživati jednu značajnu svjetsku temu koja je zanemarena u domaćoj historiografiji. Zanimljivo je to kako je jedna kompanija nastala ujedinjenjem manjih kompanija te kako je, potpomognuta od strane male i mlade države, uspjela postati vjerojatno najutjecajnija i najbogatija kompanija svih vremena. Ista je, u jednom trenutku, čak bila "država unutar države".

\section{Stanje u Europi u ranom novom vijeku i nastanak Nizozemske}

Krajem XIV. stoljeća na prostoru Nizozemske došlo je do građanskoga rata oko kontrole nad grofovijom Holland. U ovom ratu sukobili su se pripadnici konzervativnog plemstva određenih provincija i progresivni trgovački gradovi. Do sukoba dolazi jer je grofovija Holland izgubila svoga vladara i obje strane su težile da pridobiju grofoviju Holland. U građanskom ratu pobjeđuje plemstvo uz pomoć Filipa Dobrog koji je bio vojvoda Burgundije i grof Flandrije. ${ }^{2}$ Filip Dobri započeo je ujedinjavanje nizozemskih gradova pod jednim vladarom. Do tada je Nizozemska bila podijeljena između Francuske i Svetog Rimskog

2 Ur. Christopher Allmand, The New Cambridge Medieval History Volume 7., c. 1415-c. 1500, Cambridge 1998., 431-457. 
Carstva, kao i između nezavisnih gradova. Zbog rodbinskih veza s vladarskom dinastijom Francuske, Filip Dobri i njegovi nasljednici imaju lakši posao sprovođenja ujedinjenja. ${ }^{3}$

No, to ujedinjenje će doći tek nakon stupanja na vlast dinastije Habsburg, nakon izumiranja svih muški potomaka Filipa Dobrog. Do konačnog ujedinjenja dolazi 1549. godine kada Karlo V., car Svetog Rimskog Carstva, izvršava Pragmatičnu sankciju kojom formira i ujedinjuje Sedamnaest provincija. ${ }^{4}$ To će ujedinjenje kratko trajati, jer nakon abdikacije Karla V. dolazi do sukoba između njegovog sina Filipa II. s jedne strane i Engleske, Francuske, Škotske i Sedamnaest provincija s druge strane. Taj rat u historiografiji poznat je kao Osamdesetogodišnji rat u kojem Nizozemci osnivaju konfederaciju od sedam sjevernih provincija, a koja je nosila naziv Republika Sedam Ujedinjenih Niskih Zemalja ili Nizozemska Republika i Španjolska Nizozemska, koja je bila sačinjena od deset južnih provincija. ${ }^{5}$ Nizozemska Republika trajala je od 1581. do 1795. godine, a službeno je bila priznata mirom u Vestfalu. Tijekom svoga postojanja bila je jedna od najprosperitetnijih država. ${ }^{6}$

Jedan od razloga za sukob između Nizozemske Republike i Španjolske bilo je vjersko opredjeljenje Nizozemske. U Nizozemskoj je vrlo brzo došlo do širenja protestantizma, posebno kalvinizma. ${ }^{7}$ Odvajanje Nizozemske od Španjolske, a i Rimokatoličke Crkve omogućilo je rast Nizozemske koja je u jednom trenutku postala i svjetska sila.

\section{Formiranje Nizozemske istočnoindijske kompanije}

Ugovorom iz Tordesillasa iz 1494. godine između Portugala i Španjolske određeno je da će Španjolska dobiti primat na tržištu novootkrivenog kontinenta, a Portugal će dobiti primat na azijskom tržištu. Osim raspodjele novih tržišta, ovim ugovorom došlo je i do raspodjele utjecajnih sfera ovih država. Samim time u Lisabonu je osnovana Casa da India, organizacija koja je bila zadužena za trgovinu u Aziji. ${ }^{8} \mathrm{U}$ po-

3 Jeffrey Stephen Robertson, "Capitalism and accounting in the Dutch East-India Company 1602-1623: an historical study of determining influences and practices", doktorski rad, Wollongong 2011., 205-220.

4 Jonathan Israel, “The Dutch Republic: Its Rise, Greatness and Fall, 1477-1806”, U: Oxford History of Early Modern Europe, Oxford 1995., 129-155.

5 Isto, 205-233.

6 Robertson, “Capitalism and accounting", 462-466.

7 Israel, "The Dutch Republic", 361-399.

8 Piet Emmer, „The Organisation of Global Trade: The Monopoly Companies, 1600-1800“, European reveiw 22 (2014), 106-115. 
četku je ova organizacija imala uspjeh zbog svojeg monopola, ali nije uspjela iskoristiti prednost koju je imala nad drugim državama. Zbog loše organizacije, zastarjele tehnologije i manjka resursa, Portugal se mogao zadovoljiti jedino posredničkom ulogom između obilatih trgovišta Azije i bogatih trgovaca u Europi, pogotovo u Nizozemskoj. Osim toga, portugalski trgovci nisu mogli osigurati stabilan rast priljeva potrebne robe na tržišta širom Europe, što je onda znalo prouzrokovati nagli rast cijena pojedinih proizvoda, pogotovo začina. ${ }^{9}$ Nizozemski trgovci morali su prihvaćati posredničku ulogu Portugala sve do 1580. godine kada je došlo do Iberijske unije između Portugala i Španjolske, nakon čega dolazi do napetosti između Iberijske unije i Nizozemske zbog Osamdesetogodišnjeg rata. ${ }^{10}$

Ta napetost i tenzija kulminirala je 1591. godine kada dolazi do kompletnog izostavljanja nizozemskih trgovaca iz svjetske pomorske trgovine između Europe i Azije. Zbog tih događanja pojedini samostalni trgovci iz Nizozemske opremaju o svom trošku brodove za direktnu trgovinu s Azijom. ${ }^{11}$ Ovi poduhvati su bili profitabilni za trgovce, pod uvjetom da sve prođe u najboljem slučaju, a ako ne bi prošlo, tada bi ti trgovci bankrotirali i izgubili sve. Šanse za gubitak svega su bile relativno velike, čak se deset posto brodova poslanih u Aziju nikada nije vratilo u Nizozemsku. Ovaj period je trajao od 1594. do 1602. godine. U tom periodu formirano je dvanaest samostalnih kompanija koje će se 1602. godine ujediniti u Nizozemsku istočnoindijsku kompaniju. ${ }^{12}$ Ove kompanije su uvidjele lošu situaciju u kojoj su se našle. Zbog nesigurnosti na moru i jake konkurencije stranih trgovačkih kompanija, prvobitno engleskih, ali i zbog međusobne konkurencije koja ih je koštala mnogo novca, odlučili su se ujediniti u jednu snažnu kompaniju. Prvi pokušaj ujedinjenja iz 1600. godine nije uspio, ali nakon intervencije nizozemske vlade došlo je do ujedinjenja 1602. godine. ${ }^{13}$ Kao rezultat formirana je jedna snažna i stabilna kompanija, iza koje je stajala država i kojoj je dan monopol nad trgovinom s Azijom na 21 godinu. ${ }^{14}$

U takvoj organizaciji ove kompanije jasno se može vidjeti merkan-

9 Ur. Oscar Gelderblom, "The Formative Years of the Modern Corporation: The Dutch East India Company VOC, 1602-1623", U: The Journal of Economic History 73 (2013.), 1050-1076.

10 Emmer, "The Organisation", 106-115.

11 Isto.

12 Adams, "Principals and Agents, Colonialists and Company Men: The Decay of Colonial Control in the Dutch East Indies", American Sociological Review 61 (1996.), 12-28.

13 Robertson, "Capitalism and accounting", 262-298.

14 Emmer, "The Organisation", 106-115. 
tilističko ekonomsko učenje u kojem se akcenat stavlja na vanjsku trgovinu i to na pozitivnu bilancu između izvoza i uvoza. Najefikasniji način da se osigura veći izvoz je da država ili privatna kompanija ima monopol nad tržištem, da mogu sami diktirati cijene i time kontrolirati tržište. Osim toga, za veći izvoz u odnosu na uvoz, država mora imati veliko strano tržište. U merkantilističkom učenju trgovina je bila podređena državi, konkretno dobrobiti države. Sve ove faktore je ispunjavala Nizozemska istočnoindijska kompanija. ${ }^{15}$ Ona je imala monopol nad tržištem na 21 godinu koji je iskorištavala mnogo bolje nego što je to činio Portugal, a ujedno je imala i veliko strano tržište koje su sačinjavale države i regije pod upravom Nizozemske istočnoindijske kompanije. ${ }^{16}$ Te provincije bile su razgranate po Africi i Aziji. Najvažnije provincije bile su Nizozemski Mauricijus, Nizozemska Malakka, Nizozemska Indija, Cape kolonija, Nizozemski Cejlon i Nizozemska Formoza. ${ }^{17}$ Osim stranog tržišta, roba koju je dovozila Nizozemska istočnoindijska kompanija je bila cjenjena i na europskom tržištu. ${ }^{18} \mathrm{U}$ svome začetku Nizozemska istočnoindijska kompanija bila je uspostavljena na merkantilističkom ekonomskom učenju, ali ubrzo nakon osnivanja kompanije dolazi do prelaska s merkantilističkog na jedan vid kapitalističkog funkcioniranja.

\section{Stanje u Nizozemskoj istočnoindijskoj kompaniji na početku njenog rada i njen rast}

Nakon formiranja Nizozemske istočnoindijske kompanije uspostavljeno je i upravno tijelo koje je trebalo da vodi brigu o radu i stanju kompanije. To tijelo se nazivalo Heeren XVII ili Sedamnaest gospodina. ${ }^{19}$ Naziv dolazi od broja članova tog tijela. Kako je Nizozemska bila sačinjena od nekolicine snažnih gradova koji su bili trgovački orijentirani, tako je i upravno tijelo bilo sačinjeno od predstavnika različitih gradova. Točnije, postojalo je šest komora koje su predstavljale različite gradove i koje po broju članova nisu bile jednake. Tako je Amsterdamska komora imala osam članova, Zeeland komora je imala četiri, dok su Delft, Rotterdam, Hoorn i Enkhuizen imale po

15 Emmer, "The Organisation", 106-115.

16 Gelderblom, The Formative Years, 1050-1110.

17 Tonio Andrade, "Beyond Guns, Germs, and Steel: European Expansion of Maritime Asia, 1400-1750", Journal of Early Modern History 14 (2010.), 165-186.

18 Gelderblom i Jonker, Completing a Financial, 641-672.

19 Arthur Weststeijn, "The VOC as a Company-State: Debating Seventeenth-Century Dutch Colonial Expansion", Itinerario 38 (2014.), 13-34. 
jednog člana ${ }^{20}$, a postojao je i jedan slobodan član, koji nije smio biti pripadnik Amsterdamske komore. ${ }^{21}$ Ovo tijelo je imalo dva ili tri sastanka godišnje i članovi su bili birani na osam godina. Heeren XVII bili su ključni za rad i funkcioniranje Nizozemske istočnoindijske kompanije, jer su oni određivali koliko robe kompanija uvozi, određivali su koliko će kompanija imati brodova, kada će biti aukcije, koliko će koja komora morati uložiti novca i koliko će dobiti na taj ulog. Zbog tehničkih razloga nakon 1610. godine na čelu svakodnevnih operacija je bio generalni guverner koji se nalazio na posjedima Nizozemske istočnoindijske kompanije u Aziji. ${ }^{22}$

Prvi posjedi koje je prisvojila Nizozemska istočnoindijska kompanija bili su na području Zapadne Jave. Uskoro nakon uspostavljanja vlasti i trgovačkog prisustva na ovom području došli su i Englezi koji su prijetili nizozemskom monopolu nad tržištem, zbog čega je došlo do sukoba od 1610. do 1620. kada se ugovorilo primirje i sporazum između Engleske i Nizozemske istočnoindijske kompanije. Dogovor je bio da Nizozemska dobije monopol nad trgovinom na prostoru današnje Indonezije, nekih otoka i određenih obalnih dijelova Indije. Engleska bi dobila kontrolu nad ostalim dijelovima Azije. ${ }^{23}$ Nakon tog sporazuma dolazi do širenja posjeda VOC-a, koji zauzima dio otočnog arhipelaga Banda, istočno od Jave. Nizozemci su na tim otocima počinili strašne zločine nad domaćim stanovništvom. Od 15000 stanovnika koji su prvobitno živjeli na otoku nakon što je VOC osvojio arhipelag Banda preostalo je samo 1000 stanovnika. ${ }^{24}$ Kao razlog zbog kojih su počinili masovna ubojstva i raseljenja, Nizozemci su naveli da je domaće stanovništvo prekršilo sporazum između Engleske i Nizozemske, koji je garantirao monopol nad tržištem Nizozemske istočnoindijske kompanije. Nakon tih surovosti došlo je do prisilnog ugovora između domaćeg stanovništva i Nizozemske istočnoindijske kompanije. U tom ugovoru su dana sva prava nad trgovinom začinima kompaniji, a posebno je bilo naznačeno da nitko od domaćeg stanovništva ne može prodati muškantne oraščiće bilo kome drugome osim Nizozemskoj istočnoindijskoj kompaniji. ${ }^{25}$ Kazna za neposluh bila je smrt.

20 Robertson, "Capitalism and accounting", 311-317.

21 Amsterdamska komora nije mogla imati devet članova jer bi time imala većinu u upravnom tijelu.

22 Gelderblom, "The Formative Years", 1050-1110.

23 Robertson, "Capitalism and accounting", 226-235.

24 Vincent C. Loth, "Pioneers and Perkeniers: The Banda Islands in the $18^{\text {th }}$ Century", Cakalele 6 (1995), 18.

25 Adams, "Principals and Agents", 12-28. 
Ubrzo nakon rasta volumena trgovine Nizozemske istočnoindijske kompanije, ali i drugih kompanija dolazi do problema. Zbog velike potrebe europskih tržišta za začinima ${ }^{26}$ i njihove potrebe za drugom robom koja je dospijevala iz Azije, došlo je do velikog odljeva novca. Postupni odljev novca je uzrokovao paniku u Nizozemskoj i Engleskoj, kao i u drugim državama. VOC je taj problem riješio tako što je uspostavio novi sistem trgovanja u kojem su sudjelovale različite regije Azije. ${ }^{27}$ Uspostavljanje takvog jednog tržišta dovelo je do manje ovisnosti o plemenitim metalima koje su slali iz Europe ${ }^{28}$ i samim time je povećan i prihod kompanije. ${ }^{29}$ Takvo stanje je potrajalo sve do 1720. godine. VOC je vodio mnoge ratove s domaćim stanovništvom, ali to nije spriječilo da Nizozemska istočnoindijska kompanija postane najsnažnija trgovačka kompanija svih vremena.

\section{Nizozemska istočnoindijska kompanija na vrhuncu i opadanje moći}

Nakon dostizanja svog vrhunca 1720 . godine u vidu utjecaja i moći, došlo je do postupnog opadanja snage VOC-a. ${ }^{30}$ Razlog Nizozemskog jačanja slojevit je i nije moguće dati jedinstven odgovor. ${ }^{31} \mathrm{Na}$ vrhuncu svoje moći Nizozemska istočnoindijska kompanija uspjela je poslati u periodu od deset godina 382 broda u Aziju. Taj je broj poprilično velik, ako uzmemo u obzir da je Engleska istočnoindijska kompanija u istom

26 Bruce Brunton, "The East India Company: Agent of Empire in the Early Modern Capitalist Era", Social Education 77 (2013.), 78-81.

27 Oscar Gelderblom i Joost Jonker, "Completing a Financial Revolution: The Finance of the Dutch East India Trade and the Rise of the Amsterdam Capital Market, 1595-1612", The Journal of Economic History 64 (2004.), 639-672.

28 Glavna karika u tim novim tržištima bio je Japan. Razlog tome je bilo to što su Nizozemci bili jedini zapadni trgovci koji su smjeli trgovati s Japanom koji je bio bogat srebrom i zlatom. Nizozemci su imali monopol od 1634. godine kada su protjerali Portugalce.

29 Brunton, "The East India Company", 78-81.

30 F.S. Gaastra, „The Dutch East India Company's Shipping, 1602-1795, in a Comparative Perspective", U: Ships, Sailors and Spices : East India Companies and Their Shipping in the 16th, 17th and 18th Centuries, Michigan 1993., 177-193.

31 Oscar Gelderblom i Joost Jonker smatraju da je financkijska revolucija koja je zahvatila Nizozemsku bila najznačajnija karika u rastu Nizozemske istočnoindijske kompanije. Gaastra i Brujin se slažu s ovim tezama, ali naglašavaju da je veći razlog to što je Nizozemska podupirala ovu kompaniju i da je za pojedinačne trgovce bilo neisplativo da se upuštaju u tako riskantne i dugotrajne poslove. Robert Parthesius smatra da je ključni faktor bio način na koji su Nizozemci pravili svoje brodove, kao i to što su bili na većem tehnološkom nivou u odnosu na ostatak Europe u vidu potrebnih mjernih instrumenata i sprava koje su koristili u dugim putovanjima, kao i bolje i preciznije karte. 
tom vremenskom periodu poslala 149 brodova, a Francuska je tada poslala 55 brodova u Aziju. ${ }^{32}$

Na svome vrhuncu Nizozemska istočnoindijska kompanija nije samo bila fokusirana na trgovinu, nego i na proizvodnju dobara koje je kasnije plasirala ili na azijsko ili na europsko tržište, ovisno o profitnoj marži. ${ }^{33}$ Najpoznatiji proizvodi i usluge Nizozemske istočnoindijske kompanije bili su brodovi i obučavanje majstora u brodogradnji, ${ }^{34}$ uzgajanje vinove loze, šećerne trske i trgovina začinima. Osim tih proizvoda, Nizozemska istočnoindijska kompanija trgovala je i visokoprofitnim i skupocjenim proizvodima, a kada se nisu mogli domoći tih proizvoda, onda su neopravdano dizali cijene drugih proizvoda. ${ }^{35}$ Najpoznatiji slučaj takvog rada Nizozemske istočnoindijske kompanije se odnosio na uzgajanje i trgovinu tulipanima u 17. stoljeću, kada su cijene tulipana bez ikakvog logičnog i ekonomski objašnjivog razloga dosegle cijene kuća. ${ }^{36}$

U periodu od osnivanja pa do prvih desetljeća 18. stoljeća Nizozemska istočnoindijska kompanija nije bila samo ekonomska, već i vojna sila koja je zapošljavala na desetine tisuća vojnika koji su bili plaćenici iz mnogih europskih zemalja, ali i kolonija. ${ }^{37}$ Ta vojska bila im je potrebna zbog konstantnih sukoba i ratova s domorocima, ali i zbog opće napetosti i netrpeljivosti prema ostalim istočnoindijskim kompanijama. Najveći protivnik Nizozemske istočnoindijske kompanije bio je Portugal koji je u tom periodu već bio značajno oslabljen i nije se mogao oduprijeti nizozemskim upadima i otimanju zemljišta. Nizozemsko-portugalski rat trajao je od 1601. do 1661. godine. Sfere utjecaja Portugala u Aziji bile su svedene na upravu Sao Tome de Meliapore ili Mylapore, današnji grad Chennai na istočnoj obali Indijskog potkontinenta i par gradova po ostatku Azije. ${ }^{38}$ Jedan od razloga unutrašnja je nesloga i slabost same portugalske države u ovom periodu. Za razliku od Portugala, Nizozemska je uspjela nametnuti svoju ekonomsku he-

32 Gaastra, „The Dutch East India“, 177-193.

33 Adams, Principals and Agents, 12-28.

34 Čak je i Petar Veliki došao u Nizozemsku da nauči kako se proizvode brodovi i kako da i Rusi dosegnu nivo Nizozemaca.

35 Maurits Van der Veen, "The Dutch Tulip Mania: The Social Foundations of a Financial Bubble", 2009., 1-46.

36 Isto.

37 Tristan Mostert, "Chain of command: The Military System of the Dutch East India Company 1655-1663", diplomski rad, Leiden 2007., 19-25.

38 Henry Morse Stephens, Portugal, London 1891., 185-220. 
gemoniju nad domaćim stanovništvom Malakke, Šri Lanke, Tajvana i Indonezije. ${ }^{39}$ Nakon što su Nizozemska i VOC uspjeli ostvariti primat nad tržištem u Aziji i nakon što su tu ulogu preuzeli od Portugala, sukobili su se s Britanskim Carstvom i taj je sukob trajao sve do gašenja VOC-a. ${ }^{40}$

Osim što je Nizozemska preuzela dominat nad trgovinom i kontrolu nad mnogim otocima, Nizozemska je preuzela i probleme koje je imao Portugal s lokalnim stanovništvom. ${ }^{41}$ Osim tih naslijeđenih problema, Nizozemska je zbog svoje prakse porobljavanja i masakriranja domaćeg stanovništva, kao i zbog načina na koji su kontrolirali trgovinu te osiguravali svoja prava na tom prostoru, imala i netrpeljivost kod domaćeg stanovništva. ${ }^{42}$

Taj njihov način odnosa prema domaćem stanovništvu prouzrokovao je mnoge probleme za Nizozemsku istočnoindijsku kompaniju. U svom trajanju Kompanija je učestvovala u nizu samostalnih ratova protiv domaćeg stanovništva, a osim toga su i sudjelovali u ratovima Nizozemske. Lista tih ratova je dugačka, a najvažniji su nizozemsko pokoravanje Banda otočja, Javanski ratovi naslijeđa, ${ }^{43}$ ratovi za Južnu Afriku te rat između Kambodže i Kompanije. ${ }^{44}$

Nakon što je dosegao svoj vrhunac, VOC je postepeno počeo gubiti svoj utjecaj i moć. Mnogi su faktori na koje se može ukazati kao uzrok opadanja moći, ${ }^{45}$ a koji su razlog Kompanijinog poslovanja u deficitu nakon 1720. godine pa sve do njenog kraja. U ovom periodu VOC je prerasla u državu unutar države i to nije odgovaralo Nizozemskoj. Na-

39 Robert Parthesius, Dutch Ships in Tropical Waters: The Development of the Dutch East India Company (VOC) Shipping Network in Asia 1595-1600, Amsterdam 2010., 23-42.

40 Emmer, "The Organisation", 106-115.

41 Stephens, Portugal, 185-220.

42 Parthesius, Dutch Ships, 23-42.

43 Bilo ih je tri i trajali su s prekidima od 1677. do 1755. godine.

44 Adams, „Principals and Agents“, 12-28.

45 Julia Adams smatra da je razlog opadanja moći bilo udaljavanje Kompanije od Nizozemske i da su zbog toga rukovodioci Kompanije dobili neograničenu kontrolu nad njom, koju nisu mogli iskoristiti do punog potencijala. Osim toga, Adams smatra da je još jedan uzrok jačanje Britanskog Carstva na početku 18. stoljeća. Martijn Burger smatra da je razlog opadanja moći korupcija koja je bila zastupljena u čitavoj hijerarhiji. On navodi i da je kompanija propala zbog gubljenja monopola na određenim tržištima, kao i to što nisu iskoristili rastuću potrebu za opijumom, da steknu dodatni profit. Kao i Adams, Burger smatra da je glavni razlog propadanja Kompanije prouzrokovalo Britansko Carstvo. De Vries i Van de Woude smatraju da su glavni krivci za propadanje kompanije vanjski faktori na koje Kompanija nije mogla utjecati. Prije svega navode promjenu u azijskom tržištu, koja je bila nepovoljna za Nizozemce, i veliku stopu mortaliteta zaposlenih, kao i česte bolesti, koje su u kombinaciji oslabile kompaniju. 
kon četvrtog Anglo-Nizozemskog rata koji je trajao od 1780. do 1784. godine došlo je prvo do ukidanja privilegija Nizozemske istočnoindijske kompanije, da bi nakon 1796. godine Nizozemska istočnoindijska kompanija bila nacionalizirana i na kraju 1799. godine raspuštena, a svi njeni posjedi i imovina pripojeni Nizozemskoj. ${ }^{46}$

\section{Ostavština Nizozemske istočnoindijske kompanije}

Kao jedna kompanija koja je postojala skoro dvjesto godina Nizozemska istočnoindijska kompanija imala je veliki utjecaj na tadašnji svijet, ali je osim toga imala značajan utjecaj i na kasniji period, kao i utjecaj na današnjicu. On se može preopznati na raznim poljima: od ekonomije, znanstvnenih istraživanja, kartografije, brodogradnje, trgovine, diplomacije, povijesti, vojske, umjetnosti te mnogih drugih aspekata današnjeg života. Nizozemska istočnoindijska kompanija smatra se prvom megakorporacijom, prvom javnom kompanijom, prvom multinacionalnom i transnacionalnom, i prvom proto-kapitalističkom kompanijom. ${ }^{47}$ koja je imala aspekte merkantilizma i kapitalizma. ${ }^{48} \mathrm{U}$ ovom periodu dolazi do značajnog razvoja znanosti u kojem su živjeli poznati znanstvenici kao što su Antoni van Leeuwnhoek, Rene Descartes, Petrus Plancius, Abraham Rogerius, Engelbert Kaempfer, Georg Eberhard Rimphius, Louis Micahel Thibault. Oni su bili samo neki od znanstvenika koji su bili potpomognuti od strane Kompanije ili su direktno bili zaposleni. Osim njih, i poznati filozofi Tomas Hobbes, John Locke, Pierre Bayle i Spinoza su živjeli u Nizozemskoj u ovom periodu ili su bili potpomognuti od strane Nizozemske ili Kompanije. Još jedna od prednosti posjedovanja velike količine novca bila je i sponzoriranje umjetnika od strane bogatih trgovaca. Tako u ovom periodu žive i rade umjetnici kao što su Rembrant, Johannes Vermeer, Jan van Goyen, Jan Steen, Jacob van Camen i mnogi drugi. ${ }^{49}$ Osim toga mnoge zgrade napravljene od strane kompani-

46 Jan de Vries i Ad van der Woude, The First Modern Economy: Success, Failure, and Perservance of the Dutch Economy, 1500-1815, New York 1997., 454-455.

47 Jairus Banaji, „Islam, the Mediterranean and the rise of capitalism“, Journal of Historical Materialism 15 (2007.), 47-74.

48 Zbog velikog utjecaja države na određene aspekte rada Nizozemske istočnoindijske kompanije, kao i zbog težnje da održe pozitivnu bilancu u vanjskoj trgovini. Dok su njene kapitalističke odlike bile te da je svoje financiranje i potreban novac za pokretanje trgovačkih ekspedicija dobivala od privatnih investitora. Osim toga, Nizozemska istočnoindijska kompanija bila je prva kompanija koja je izašla na burzu i s čijim dionicama se moglo trgovati.

49 Joop de Jong, "The Dutch Golden Age of Globalization: History and Heritage, Legacies and 
je danas se nalaze na UNESCO-voj listi svjetske kulturne baštine. Na toj listi nalaze se gradovi kao što su Malacca i Galle, a sva arhiva Kompanije je proglašena UNESCO-vom memorijom svjetskog registra. ${ }^{50}$

Čak postoji i kontroverzan izraz koji se koristi u Nizozemskoj, a to je "VOC mentalitet". ${ }^{11}$ Taj izraz je kontroverzan jer je s jedne strane Kompanija zaslužna za značajan napredak u svijetu, kao što je bila zaslužna za širenje ujecaja i moći Nizozemske, ali je ujedno izrabljivala i ubijala domaće stanovništvo koje je pronalazila na prostorima kojima je upravljala. Poznati su mnogi masakri i porobljavanje domorodačkog stanovništva, kao i kaznene ekspedicije koje su imale zastrašujuće posljedice.

\section{Prilozi}

\begin{tabular}{|c|c|c|c|}
\hline & VOC & EIC & Francuzi \\
\hline $1600-1610$ & 76 & 17 & 2 \\
\hline $1610-1620$ & 117 & 77 & 10 \\
\hline $1620-1630$ & 141 & 58 & 0 \\
\hline $1630-1640$ & 157 & 59 & 6 \\
\hline $1640-1650$ & 164 & 75 & 6 \\
\hline $1650-1660$ & 206 & 81 & 24 \\
\hline $1660-1670$ & 238 & 91 & 30 \\
\hline $1670-1680$ & 232 & 131 & 35 \\
\hline $1680-1690$ & 204 & 142 & 36 \\
\hline $1690-1700$ & 235 & 80 & 38 \\
\hline $1700-1710$ & 280 & 120 & 41 \\
\hline $1710-1720$ & 311 & 127 & 55 \\
\hline $1720-1730$ & 382 & 149 & 109 \\
\hline $1730-1740$ & 375 & 154 & 124 \\
\hline $1740-1750$ & 314 & 184 & 135 \\
\hline $1750-1760$ & 291 & 191 & 105 \\
\hline $1760-1770$ & 292 & 242 & 194 \\
\hline $1770-1780$ & 290 & 229 & 303 \\
\hline $1780-1790$ & 297 & 292 & 196 \\
\hline $1790-1795$ & 118 & 177 & 1455 \\
\hline $1600-1795$ & 4720 & & \\
\hline
\end{tabular}

Prilog 1. Prikaz broja brodova Francuske, Engleske

i Nizozemske istočnoindijske kompanije ${ }^{52}$

Contestation", Macalaster International 27 (2011.), 46-67.

50 http://www.unesco.org/new/en/communication-and-information/memory-of-theworld/register/full-list-of-registered-heritage/registered-heritage-page-1/archives-ofthe-dutch-east-india-company/ (18. 12. 2018.)

51 https://c3am.nl/voc-mentaliteit/ (18. 12. 2018.)

52 Gaastra, "The Dutch", 182. 


\begin{tabular}{|c|c|c|c|c|}
\hline \multicolumn{3}{|c|}{ Izvoz } & \multicolumn{2}{|c|}{ Uvoz } \\
\hline & Broj brodova & Tonaža & Broj brodova & Tonaža \\
\hline $1602-1610$ & 76 & 34,970 & 49 & 22,580 \\
\hline $1610-1620$ & 117 & 56,280 & 50 & 29,130 \\
\hline $1620-1630$ & 141 & 54,720 & 71 & 37,380 \\
\hline $1630-1640$ & 157 & 63,970 & 75 & 40,300 \\
\hline $1640-1650$ & 164 & 100,950 & 93 & 74,240 \\
\hline $1650-1660$ & 206 & 123,990 & 103 & 84,560 \\
\hline $1660-1670$ & 238 & 129,349 & 127 & 89,240 \\
\hline $1670-1680$ & 232 & 147,647 & 133 & 99,132 \\
\hline $1680-1690$ & 204 & 130,849 & 141 & 105,322 \\
\hline $1690-1700$ & 235 & 143,295 & 156 & 108,123 \\
\hline $1700-1710$ & 280 & 186,364 & 193 & 135,407 \\
\hline $1710-1720$ & 311 & 228,066 & 245 & 185,274 \\
\hline $1720-1730$ & 382 & 289,233 & 319 & 251,662 \\
\hline $1730-1740$ & 375 & 280,035 & 311 & 236,640 \\
\hline $1740-1750$ & 314 & 252,715 & 234 & 185,605 \\
\hline $1750-1760$ & 291 & 278,845 & 244 & 237,760 \\
\hline $1760-1770$ & 292 & 291,605 & 233 & 231,720 \\
\hline $1770-1780$ & 290 & 290,340 & 244 & 245,500 \\
\hline $1780-1790$ & 297 & 243,424 & 228 & 170,923 \\
\hline $1790-1795$ & 118 & 80,717 & 113 & 92,520 \\
\hline
\end{tabular}

Prilog 2. Prikaz količine robe koja je prevezena ${ }^{53}$

\section{Zaključak}

Nizozemska istočnoindijska kompanija je sasvim sigurno promijenila tijek razvitka čovječanstva i utjecala na suvremeni svijet. Njena praksa i način poslovanja dovela je do zbližavanja Istoka i Zapada, Azije i Europe. Značaj koji je imala dobrim je dijelom narušen njenim postupcima i načinom tretiranja neeuropljana s kojima su imali dodira i s kojima su obavljali posao.

Njen značaj u današnjem svijetu se ne odbacuje, ali se gleda s neodobravanjem I određenom dozom prijekora od strane Nizozemaca, ali i Europljana. Potrebno je napomenuti da se Zapad nije ni danas mnogo udaljio od praksi Nizozemske istočnoindijske kompanije. Bilo kako bilo, značaj ove kompanije je neizmjerljiv i njen utjecaj na sadašnjicu je neupitan. Njene metode bile su brutalne i krvave, a proizvod koristan samo za Europu.

Nizozemska istočnoindijska kompanija bila je mnogo toga: od multinacionalne kompanije koja je upošljavala na desetine tisuća ljudi na tri kontinenta i u mnogobrojnim državama, regijama i samostalnim 
gradovima. Njen ekonomski ustroj i način rada doveo je do nastanka jedne kompanije koja je imala karakteristike i model poslovanja kakav imaju sadašnje kapitalističke tvrtke. Treba napomenuti da je ova kompanija formirana na samom početku 17. stoljeća i da je kroz svoj rad osigurala postojanje sve do konca 18. i početka 19 stoljeća.

Kontroverzna prošlost Nizozemske istočnoindijske kompanije posljednjih desetljeća je dovela do toga da su se formirala dva tabora u Nizozemskoj. Jedan koji povoljno gleda na način poslovanja Kompanije i opravdava, a drugi koji se distancira u potpunosti od Kompanije. Kao i svaka kontroverzna tema, tako se i Nizozemska istočnoindijska kompanija treba proučavati i rezultate tih izučavanja prihvatiti, ma kakvi oni bili i shodno tim saznanjima da pokušamo raditi moralno $u$ daljem napredovanju.

\section{Bibliografija}

\section{Knjige i članci}

Adams, Julia, „Principals and Agents, Colonialists and Company Men: The Decay of Colonial Control in the Dutch East Indies". American Sociological Review 61 (1996): 12-28.

Allmand, Christopher, ur. „The New Cambridge Medieval History Volume 7, c.1415c.1500", Cambridge University Press, 1998.

Andrade, Tonio, „Beyond Guns, Germs, and Steel: European Expansion and Maritime Asia, 1400-1750", Journal of Early Modern History 14 (2010): 165-186.

Banaji, Jairus, „Islam, the Mediterranean and the rise of capitalism”. Journal Historical Materialism 15 (2007): 47-74.

Brunton, Bruce. „The East India Company: Agent of Empire in the Early Modern Capitalist Era", Social Education 77 (2013): 78-81.

de Vries, Jan i van der Woude, Ad. The First Modern Economy: Success, Failure, and Perseverance of the Dutch Economy, 1500-1815. New York: Cambridge University Press, 1997.

Emmer, Piet, „The Organisation of Global Trade: The Monopoly Companies, 16001800“. European Review 22 (2014): 106-115.

Gaastra, F. S, "The Dutch East India Company's Shipping, 1602-1795, in a Comparative Perspective." Ships, Sailors and Spices: East India Companies and Their Shipping in the $16^{\text {th }}, 17^{\text {th }}$ and $18^{\text {th }}$ Centuries (1993): 177-193.

Gelderblom, Oscar i Jonker, Joost, "Completing a Financial Revolution: The Finance of the Dutch East India Trade and the Rise of the Amsterdam Capital Market, 1595-1612". The Journal of Economic History 64 (2004): 641-672.

Gelderblom, Oscar, ur. „The Formative Years of the Modern Corporation: The Dutch East India Company VOC, 1602-1623". The Journal of Economic History 73 
(2013): 1050-1076.

Israel, Jonathan, "The Dutch Republic: Its Rise, Greatness and Fall, 1477-1806" Oxford History of Early Modern Europe, 1995.

de Jong, Joop, "The Dutch Golden Age and Globalization: History and Heritage, Legacies and Contestations," Macalester International 27 (2011): 46-67.

Loth, Vincent C, "Pioneers and Perkeniers: The Banda Islands in the 18th Century", Cakalele 6 (1995): 13-35.

Mostert, Tristan, "Chain of command: The military system of the Dutch East India Company 1655-1663", Universiteit Leiden, 2007.

Parthesius, Robert, Dutch Ships in Tropical Waters: The Development of the Dutch East India Company (VOC) Shipping Network in Asia 1595-1660, Amsterdam University Press, 2010.

Robertson, Jeffrey Stephen, „Capitalism and accounting in the Dutch East-India Company 1602-1623: a historical study of determining influences and practices", Doctor of Philosophy thesis, School of Accounting and Finance, University of Wollongong, 2011.

Stephens, Henry Morse, "Portugal", T. F. Unwin, 1891.

van der Veen, Maurits, "The Dutch Tulip Mania: The Social Foundations of a Financial Bubble", 2009.

Weststeijn, Arthur, „The VOC as a Company-State: Debating Seventeenth-Century Dutch Colonial Expansion“. Itinerario 38 (2014): 13-34.

\section{Internetski izvori}

https://c3am.nl/voc-mentaliteit/ (18. 12. 2018.) http://www.unesco.org/new/en/communication-and-information/memory-ofthe-world/register/full-list-of-registered-heritage/registered-heritage-page-1/ archives-of-the-dutch-east-india-company/ (18.12. 2018.)

\section{SUMMARY}

The Dutch East India Company is one of the most important companies in the history of mankind. Throughout the many years of its existence the Dutch East India Company changed the stale economic practices and introduced new ones, some of which are still relevant nowadays. This paper gives a brief overview of the history of the Dutch East India Company starting from the founding of the Netherlands to it growing strong enough to rival even the England itself. Chronology of the Dutch East India Company presented in this paper follows the company from its creation until its shutdown as well as its achievements that have been made during the company's existence.

Keywords: Dutch East India Company, England, Netherlands 